\title{
Medical Technologist
}

National Cancer Institute

\section{Source}

National Cancer Institute. Medical Technologist. NCI Thesaurus. Code C53418.

A person with professional knowledge and competence in the field of medical technology that involves performing, advising on, or supervising clinical laboratory testing of human specimens, fluids and tissues, establishing and monitoring quality control systems and measures; developing data which may be used in clinical setting and in support of medical research in such areas as hematology, bacteriology, mycology, virology, parasitology, immunology, serology, immunohematology, clinical chemistry, endocrinology and toxicology, and urinalysis as they relate to clinical laboratory practice. The concept does not refer to professionals primarily involved in technical support work concerned with operating medical machines or instruments as part of the examination or treatment of patients. 